\title{
THE EFFECT OF ADHERENCE TO IRON TABLET TAKING AND OTHER FACTORS ON THE RISK OF ANEMIA IN PREGNANT MOTHERS IN BANTUL, YOGYAKARTA
}

\author{
Mulya Cunda Ratu Reso'), Yulia Lanti Retno Dewi²), \\ Uki Retno Budihastuti2) \\ ${ }^{1)}$ Masters Program in Public Health, Universitas Sebelas Maret \\ 2)Faculty of Medicine, Universitas Sebelas Maret \\ 3)Department of Obstetrics and Gynecology, Dr. Moewardi Hospital, Surakarta
}

\begin{abstract}
Background: Pregnant women are at a higher risk for developing anemia due to the excess amount of blood the body produces to help provide nutrients for the infant. They are recommended for routine iron tablets consumption. The purpose of this study was to examine the effect of adherence to iron tablet taking and other factors on the risk of anemia in pregnant mothers in Bantul, Yogyakarta.

Subjects and Method: This was a cross-sectional study carried out at Bambanglipuro community health center, Bantul, Yogyakarta, Indonesia, from March to April 2019. A sample of 200 pregnant women was selected by fixed disease sampling. The dependent variable was anemia. The independent variables were age, gestational age, parity, birth spacing, education, income, iron tablet consumption, contraceptive use, dietary pattern, and body mass index. The data were collected by questionnaire and analyzed by a multiple logistic regression.

Results: The risk of anemia among pregnant women increased with education $<$ senior high school ( $\mathrm{OR}=4.34$; $95 \% \mathrm{CI}=0.96$ to 19.63 ; $\mathrm{p}=0.032)$, age $<20$ or $\geq 35$ years $(\mathrm{OR}=$ 3.82 ; $95 \% \mathrm{CI}=0.92$ to $15.97 ; \mathrm{p}=0.047)$, parity $\geq 3$ times $(\mathrm{OR}=4.08 ; 95 \% \mathrm{CI}=1.10$ to $15.08 ; \mathrm{p}=0.035)$, birth spacing $<2$ years $(\mathrm{OR}=9.55 ; 95 \% \mathrm{CI}=1.90$ to $48.00 ; \mathrm{p}=0.006)$, gestational age at second or third trimester $(\mathrm{OR}=7.16 ; 95 \% \mathrm{CI}=1.35$ to $38.06 ; \mathrm{p}=$ 0.021), $\mathrm{BMI}(\mathrm{OR}=5.15 ; 95 \% \mathrm{CI}=1.06$ to $24.96 ; \mathrm{p}=0.042)$, low income $(\mathrm{OR}=5.01 ; 95 \%$ $\mathrm{CI}=1.18$ to $21.24 ; \mathrm{p}=0.029)$, poor dietary pattern $(\mathrm{OR}=5.53 ; 95 \% \mathrm{CI}=1.03$ to $29.69 ; \mathrm{p}=$ 0.046), contraceptive use $(\mathrm{OR}=5.47 ; 95 \% \mathrm{CI}=1.36$ to $22.01 ; \mathrm{p}=0.017)$, and noncompliance in iron uptake $(\mathrm{OR}=5.03 ; 95 \% \mathrm{CI}=1.32$ to $19.14 ; \mathrm{p}=0.018)$.

Conclusion: The risk of anemia among pregnant women increases with education $<$ senior high school, age $<20$ or $\geq 35$ years, parity $\geq 3$ times, birth spacing $<2$ years, gestational age at second or third trimester, BMI, low, poor dietary pattern, contraceptive use, and non-compliance in iron uptake.
\end{abstract}

Keywords: anemia, pregnant women, iron uptake, body mass index

\section{Correspondence:}

Mulya Cunda Ratu Reso. Masters Program in Public Health, Universitas Sebelas Maret. Jl. Ir. Sutami 36A, Surakarta 57126, Jawa Tengah. Email: mulyacund@gmail.com. Mobile: 082138095480. 